\title{
Dari pasanggrahan hingga grand hotel. AKOMODASI PENGINAPAN UNTUK TURIS PADA MASA hINDIA-BelaNda DI PRIANGAN (1869-1942)
}

\author{
FROM GUEST HOUSE TO GRAND HOTEL: \\ LODGING ACCOMODATION FOR TOURISTS \\ DURING THE DUTCH EAST INDIES COLONIAL IN PRIANGAN (1869-1942)
}

\author{
Andi Arismunandar ${ }^{1}$, Reiza D. Dienaputra ${ }^{2}$, R. M. Mulyadi ${ }^{3}$ \\ 1,2,3 Jurusan Ilmu Sejarah Universitas Padjadjaran \\ Jalan Raya Bandung Sumedang Km. 21 Jatinangor \\ e-mail: ${ }^{1}$ andiarism92@ gmail.com, ${ }^{2}$ reizaputra@ unpad.ac.id, ${ }^{3}$ r.m.mulyadi@unpad.ac.id
}

DOI: 10.30959/patanjala.v12i2.571

\begin{abstract}
Abstrak
Pada periode akhir masa kolonial Belanda di Hindia, semakin banyak turis yang berkunjung. Priangan yang merupakan primadona kunjungan wisata pada masa itu, tentunya harus menata diri untuk melayani para turis yang berkunjung. Akomodasi penginapan dalam dunia pariwisata adalah hal yang pokok untuk tersedia dan memadai di lokasi-lokasi yang akan dituju oleh para turis. Berbagai kisah menarik mengenai perkembangan akomodasi penginapan membawa nilai positif bagi para turis yang berkunjung ke Priangan berdasarkan sumber-sumber yang ditemukan oleh penulis. Maka, untuk menjabarkan persoalan tersebut dibutuhkan kajian historis dengan menggunakan metode sejarah, terdiri atas heuristik, kritik, interpretasi, dan historiografi. Berdasarkan penelitian yang dilakukan ini, bahwa pariwisata baru mulai menggeliat ketika memasuki akhir abad ke-19 di mana Pesanggrahan dan Hotel semakin berkembang sebagai jawaban untuk memenuhi kebutuhan penginapan bagi para turis. Dari berbagai sumber yang coba penulis baca dan telaah, dapat diketahui mengenai perkembangan akomodasi penginapan pariwisata pada masa kolonial Hindia Belanda.
\end{abstract}

Kata kunci: akomodasi penginapan, pariwisata, Priangan.

\begin{abstract}
During the late Dutch colonial period in the Dutch East Indies, more and more tourists visited. As a result, Priangan, which was the most favorite tourist destination at that time, certainly had to manage itself better to serve the tourist visits. Therefore, the availability of adequate lodging accommodation in the world of tourism was a mandatory requirement, especially in tourist destinations. Referring the sources found by the author, there are various interesting stories about the development of lodging accommodation with a positive impact on tourists in Priangan. To describe this problem, a historical study is needed using the historical method consisting of heuristics, criticism, interpretation, and historiography. Based on the research conducted, it was revealed that tourism in Priangan first began to grow towards the end of the $19^{\text {th }}$ century as indicated by the growing number of guest houses and hotels in response to meet the lodging needs of tourists. The results of the analysis of various sources used as a reference in this study indicate
\end{abstract}


that the development of tourism accommodation during the Dutch East Indies colonial had a positive impact on the progress of tourism in Priangan.

Keywords: lodging accommodation, hotel, tourism, Priangan.

\section{A. PENDAhuluan}

Berkembangnya kepariwisataan dengan segala macam mekanisme dan pengaturannya yang cukup kompleks terkait pergerakan turis dengan segala aktivitas sudah barang tentu melibatkan banyak aspek, antara lain: transportasi, penginapan, restoran, pemandu wisata, hiburan dan sarana lain-lain. Secara umum kita mengetahui bahwa hubungan akomodasi dan atau penyediaan fasilitas pendukung dengan pariwisata saling berkaitan sangat erat. Ini tak lepas dari fakta bahwa salah satu tulang punggung yang mendukung pembangunan sektor pariwisata adalah sektor akomodasi.

Banyak sekali kontribusi dari tersedianya akomodasi penginapan yang berimplikasi bagi perkembangan pariwisata. Guna memenuhi semua kebutuhan tersebut, maka keberadaan hotel dan penginapan menjadi sangat dimungkinkan sebagai salah satu sarana penunjang yang paling penting atau bisa disebut sarana pokok kepariwisataan sehingga para turis yang datang dan atau berkunjung di suatu tempat akan terpenuhi akomodasinya. Semakin pesatnya perkembangan pariwisata dampaknya akan berkaitan langsung dan menggairahkan aktivitas di bidang akomodasi penginapan. Di sinilah usaha akomodasi penginapan mempunyai keterkaitan dengan pariwisata, tanpa pertumbuhan pariwisata sangat mungkin kondisi hotel dan sejenisnya pun akan menjadi lesu. Demikian halnya, tanpa tersedianya salah satu akomodasi penunjang kegiatan wisata berupa hotel atau penginapan bagi turis maka kepariwisataan menjadi kurang nyaman dan turis pasti akan sangat kesulitan untuk memenuhi kebutuhannya berkaitan dengan kegiatan wisata yang lebih dari satu hari.

Pertumbuhan kepariwisataan dan perkembangannya yang semakin meningkat bahkan sudah memasuki industri wisata di era pasar bebas seperti sekarang, usaha perhotelan pun mengikutinya. Daya jual pariwisata di Hindia Belanda yang unik dengan kelebihan alamnya yang eksotis, semakin 'laris manis' dan cenderung banyak dikunjungi turis asing atau turis mancanegara dan berdampak pula pada tingkat hunian hotel. Ini tidak lain merupakan hukum sebab-akibat dimana kedua bidang ini saling melengkapi sehingga terus eksis dan layak mendapat perhatian pemerintah maupun pihak pengusaha yang bersangkutan.

Pariwisata berkembang karena adanya gerakan manusia di dalam mencari sesuatu yang belum diketahuinya, menjelajahi wilayah yang baru, mencari perubahan suasana, atau untuk mendapat perjalanan baru. Sesungguhnya, pariwisata telah dimulai sejak dimulainya peradaban manusia itu sendiri, ditandai oleh adanya pergerakan manusia yang melakukan ziarah dan perjalanan agama lainnya. Sebagai fenomena modern, tonggaktonggak bersejarah dalam pariwisata dapat ditelusuri dari perjalanan Marcopolo (1254-1324) yang menjelajahi Eropa, sampai ke Tiongkok, untuk kemudian kembali ke Venesia, yang kemudian disusul perjalanan Pangeran Henry (13941460), Cristopher Colombus (1451-1506), dan Vasco da Gama (akhir abad XV). Namun, sebagai kegiatan ekonomi, pariwisata baru berkembang pada awal abad 19 dan sebagai industri internasional pariwisata dimulai tahun 1869 (Graburm dan Jafari, 1991:211).

Bagi Indonesia, jejak pariwisata dapat ditelusuri kembali pada dasawarsa awal abad 20, yang ditandai dengan dibentuknya VTV (Vereeneging Toeristen Verkeer), sebuah badan pariwisata Belanda, berkedudukan di Batavia. Badan pemerintah ini sekaligus juga bertindak 
sebagai tour operator dan travel agent, yang secara gencar mempromosikan Indonesia (khususnya Jawa, kemudian Bali). Pada tahun 1926 berdiri pula di Jakarta sebuah cabang dari Lislind (Lissonne Lindeman) yang pada 1928 berubah menjadi Nitour (Nederlandsche Indische Touristen Bureau), sebagai anak perusahaan dari Koninklijke Paaketvart Maatschapij (KPM) perusahaan pelayaran Belanda. KPM secara rutin melayani pelayaran yang menghubungkan Batavia, Surabaya, Bali, dan Makasar, dengan mengangkut turis (Spillane, 1987: 38)

Pariwisata massal adalah fenomena yang dianggap relatif muda dan, meskipun tingkat pertumbuhannya luar biasa, tetapi masih ditandai sebagai sesuatu belum matang atau baru saja mencapai kematangan, terutama sebagai suatu bidang studi akademis. Ada masalah definitif dalam kaitannya dengan pariwisata dan ini pada gilirannya menyebabkan munculnya apa yang disebut dengan kesulitan pengukuran. Tiga elemen dasar dalam sistem pariwisata yaitu, turis itu sendiri (aktor dalam sistem), elemen geografis (daerah penghasil turis, daerah tujuan wisata dan daerah rute wisata) serta industri pariwisata (bisnis dan organisasi yang terlibat dalam pengiriman produk pariwisata). Interaksi antara elemenelemen tersebut dalam hal transaksi dan dampak. Penting untuk menyoroti hubungan, terutama di kalangan akademik dimana divisi mata pelajaran sering dibuat yang mencegah apresiasi penuh terhadap hubungan dan transaksi. Pariwisata memiliki banyak manfaat positif termasuk bagi beberapa negara, menjadi sebuah sumber utama penciptaan lapangan kerja dan pendapatan. Namun, ada juga konsekuensi negatif dari pariwisata, termasuk kerusakan yang berdampak pada lingkungan dan tradisi atau populasi lokal. Vellas dan Becherel (1995: xxii) menjelaskan tentang pariwisata internasional sebagai "salah satu fenomena paling berpengaruh dalam perkembangan ekonomi dan sosial masyarakat kita".
Akomodasi merupakan "sub-sektor yang terbesar dan paling banyak ditemukan dalam ekonomi pariwisata" (Cooper, 1998: 313). Tidak hanya sebagian besar bagian dari industri perjalanan atau wisata - jika tidak bisa dikatakan semua, para turis tentunya memerlukan akomodasi penginapan untuk bermalam selama perjalanan yang mereka lalui, atau mungkin untuk tinggal beberapa hari baik itu di lokasi tujuan maupun di daerah transit, tetapi juga pengeluaran untuk akomodasi biasanya merupakan elemen paling signifikan dari total pengeluaran biaya seorang turis.

Kajian ini berusaha memberikan gambaran dan mendiskusikan mengenai dinamika turisme pada masa kolonial di Priangan berkaitan dengan akomodasi, terutama akomodasi penginapan dan pengaruhnya sebagai sarana penunjang kegiatan wisata terhadap pertumbuhan pariwisata itu sendiri.

Adapun aspek spasial dan temporal yang dijadikan batasan dalam penelitian ini yaitu Karesidenan Priangan sebagai aspek spasialnya, yang nanti pada pemaparan temuan juga akan dibahas mengenai kotakota di sekitarnya seperti Buitenzorg dan Soemedang. Kemudian untuk temporalnya, dimulai dari tahun 1869 yang merupakan tonggak dimulainya pariwisata sebagai sebuah industri yang bersifat mancanegara, hal tersebut dibuktikan dengan terjadinya kunjungan-kunjungan lintas negara dan jumlah pengunjung dari Eropa meningkat untuk tujuan wisata. Periode yang diteliti diakhiri pada tahun 1942, yang mana tahun tersebut merupakan akhir dari masa kolonialisme Belanda di Hindia.

Beberapa pertanyaan yang diajukan adalah bagaimana perkembangan akomodasi pendukung pariwisata pada masa kolonial di Priangan, fasilitasfasilitas apa saja yang disediakan oleh beberapa penginapan yang ada di Priangan, apa pengaruhnya dari layanan akomodasi penginapan terhadap perkembangan industri pariwisata masa kolonial di Priangan. Sumber-sumber yang digunakan 
adalah sumber resmi tercetak, sumber sekunder serta sumber primer yang telah dibukukan serta gambar-gambar pendukung.

\section{B. METODE PENELITIAN}

Penelitian ini menggunakan metode sejarah yang terdiri atas heuristik, kritik, interpretasi, dan historiogarfi. Tahapan pertama yang dikerjakan dari metode sejarah adalah heuristik. Pada tahapan ini penulis mencari dan menghimpun sumber, informasi, yang berasal dari masa lampau yang berkaitan dengan objek yang sedang diteliti (Herlina, 2008: 7-15). Setelah sumber terhimpun, maka dilakukan tahap kedua yaitu kritik. Tahap ini terdiri atas kritik eksternal dan kritik internal. Kritik eksternal dilakukan dengan meneliti keaslian sumber dan kritik internal dengan meneliti kredibilitas sumber (Kuntowijoyo, 2013: 77-78). Sebagaimana yang dikemukakan oleh Sjamsuddin (2012: 103) bahwa kritik harus dilakukan agar penulis tidak menerima begitu saja apa yang tercantum dan tertulis pada sumber-sumber tersebut.

Tahap ketiga disebut dengan interpretasi. Interpretasi sendiri terdiri atas analisis (menguraikan) dan sintesis (menyatukan). Interpretasi disebut sebagai biang subjektivitas. Oleh karena itu, pada tahap ini, penulis harus mengambil jarak dengan sumber agar tidak terlalu dekat dan menimbulkan bias. Terdapat beberapa jenis interpretasi, yaitu interpretasi verbal, teknis, logis, psikologis, dan faktual.

Tahap akhir dari metode sejarah disebut dengan historiografi atau kegiatan menuliskan hasil dari penelitian yaitu mengenai perkembangan akomodasi penginapan di Priangan untuk keperluan turisme. Dalam tahap ini yang diperlukan adalah kemampuan menulis. Seperti diungkapkan oleh Mary Fulbrook, "To write history requires a leap of the imagination. To write history requires a degree of creativity. To write history recquires active, critical powers of selection, analysis, representation"
(Fulbrook, 2002: 53). Sebuah tulisan yang kreatif tentu membutuhkan kecerdasan dengan bersikap kritis terhadap setiap sumber dan imajinasi agar penulis mampu membayangkan bagaimana sebuah peristiwa terjadi.

\section{HASIL DAN BAHASAN \\ 1. Priangan dan Geliat Pariwisata di Hindia Belanda}

Setelah kekuasaan VOC berakhir maka secara resmi Hindia-Belanda merupakan daerah koloni kerajaan Belanda terhitung 1 Januari 1800. Sejak saat itu pula Kerajaan Belanda berhak mencampuri urusan pemerintahan di Hindia-Belanda serta para penduduknya berada di bawah kekuasaan Kerajaan Belanda (Termorshuizen, 1993: 9). Segala hal diatur dan dibuat peraturannya (besluit) oleh pemerintahan Kolonial. Pada tahun 1821 ada sebuah aturan yang membatasi kunjungan orang asing ke Hindia-Belanda, mereka yang datang ke Hindia dan hendak bepergian ke daerah lain harus meminta izin kepada penguasa setempat. Bagi yang melanggar harus menghadapi sanksi, dalam bentuk hukuman denda maupun kurungan ${ }^{1}$.

\footnotetext{
${ }^{1}$ Adalah aturan pas (passenstelsel) bagi Vreemde Oosterlingen (orang Timur Asing) yang dikeluarkan oleh Gubernur Jenderal G.A.G.Ph. Baron van der Capellen tanggal 9 Januari 1821 berkenaan dengan Staatsblad No. 6. Isi sebenarnya aturan itu adalah wilayah Keresidenan Priangan tertutup bagi semua orang Eropa dan Tionghoa, kecuali mereka yang telah mendapatkan izin dari Residen Priangan. Lihat pula izin memasuki wilayah Hindia-Belanda bagi orang Eropa dan sederajat dalam Koninklijk Besluit No. 1 tanggal 15 September 1871, Indische Staatsblad 1872 No. 38 yang kemudian diubah dalam Indische Staatsblad 1881 No. 226, 1890 No. 186. Lalu aturan Toelatingskaart (kartu izin) bagi para pendatang untuk memasuki wilayah binnenlanden (pedalaman) di Jawa. Lihat pengalaman seorang pelancong Amerika Eliza R. Scidmore dalam Java: the Garden of the East (1984: 40).
} 
Penyebutan Priangan untuk dataran tinggi di Jawa Barat dapat ditelusuri sejak masa kolonial awal. Nama Priangan atau Parahyangan memiliki beberapa arti. Salah satu artinya adalah kawasan yang menjadi liar dan tidak berpenduduk lagi. Hal itu mengacu pada kelumpuhan masyarakat sebagai dampak dari kejatuhan dan kehancuran Kerajaan Hindu Pajajaran. Tentang sejarah, susunan, dan luas negara prakolonial ini, yang pusatnya terletak di dekat Bogor sekarang, tidak banyak diketahui. Keberadaannya di abad ke-14 dan ke-15 terbukti dari sejumlah temuan arkeologis yang menunjukkan masa lalu hinduistis, tetapi tidak menjelaskan sifat sistem masyarakat petani yang melandasinya.

Kendati Priangan sebelum abad ke19 hingga awal abad ke-20 menampilkan sebuah wilayah yang pada mulanya masih berupa daerah di pedalaman (Breman, 2014: 22), mulai memainkan peranan pedalaman dalam konstelasi politik Hindia-Belanda kolonial. Hingga kemudian, Priangan terutama Bandung mampu bertransformasi menjadi salah satu kota kolonial Hindia-Belanda modern. Ketika Belanda mendirikan Bandung, awalnya Belanda tampak tidak memiliki visi untuk menjadikan kota ini sebagai kota kolonial modern. Barulah di pertengahan abad ke-19, Belanda mulai memvisikan kota ini sebagai suatu kota kolonial modern. Dan, visi ini terus berlanjut hingga menjelang pertengahan abad ke-20, dimana Bandung dibangun hanya demi kenyamanan kelompok masyarakat Eropa saja. Sementara, orang-orang Pribumi sebagai kelompok mayoritas hidup di pinggiran kota.

Pada abad ke-19 Dunia Tropis yang terbentang di khatulistiwa menjadi fantasi yang terbayangkan terutama oleh orangorang di belahan bumi utara seperti Amerika dan Eropa. Pesona dan eksotisme alam tropis seakan menyihir para petualang, evolusionis, ilmuwan, orientalis dan masyarakat awam dari Amerika dan Eropa untuk datang mengeksploitasi dan menjelajahi wilayah ini. David Weir menyebut hal ini sebagai Terra Fantastica (Weir, 2011: 2)

Dunia tropis seakan menghadirkan sihir dan magnet yang menarik bagi orangorang kulit putih untuk datang ke wilayah ini. Kekayaan dan keanekaragaman flora dan fauna; pesona budaya Timur yang eksotis dan menawan; dunia alam liar yang penuh dengan misteri; kehidupan manusia yang masih sederhana dan tradisional menjadi imajinasi yang menumbuhkan rasa penasaran dari para orang kulit putih untuk datang dan berkunjung. Hal ini pun ditambah oleh berbagai foto, buku, dan cerita perjalanan dari orang-orang yang pernah mengunjungi daerah-daerah tropis termasuk Priangan.

Sementara itu di Priangan Timur, semakin tersohor ke dunia luar setelah kedatangan Nicholas Alexandrovich, pewaris takhta Kekaisaran Rusia, yang kali pertama mempopulerkan Garut. Putra Tsar Alexander III itu mengunjungi Garut pada Maret 1891 bersama Pangeran George II, putra mahkota Kerajaan Yunani.

Berita dalam surat kabar Bintang Barat, menuliskan bahwa pada Maret 1891;

Tanah Priangan kedatangan tamu, yaitu anak Raja Rusia. Anak raja ini diceritakan berburu babi hutan di Cikurai. Bertemu jurang besar dan dalem di antara dua miringnja gunung $2800 \mathrm{~m}$ di atas laut. Anak raja gagah menembak bunuh 13 babi hutan (Bintang Barat, 10 Maret 1891).

Selama dua hari di Garut, Anak Raja Rusia dua hari tinggal di rumah Bupati Garut. Disebutkan bahwa Bupati Garut mendapat hadiah cincin emas dari anak Raja Russia ketika hendak kembali ke Batavia. Walaupun dalam artikel surat kabar tersebut tidak disebutkan nama anak Raja Russia yang berkunjung ke tanah Priangan. Namun Ajay Kamalakaran menulis di dalam harian daring Russia Beyond The Headlines mengkonfirmasikan 
nama Nicholas II (1868-1918), Tsar Rusia terakhir yang memerintah pada 1894 hingga 1918. Artikel ini membenarkan perjalanan putra mahkota dari Batavia ke stasiun Bogor sebelum melakukan perjalanan ke Bandung. Buku harian Nicholas II menunjukkan bahwa ia secara fisik kelelahan saat ia berada di Hindia Timur serta panas dan kelembaban membuatnya bahkan lebih buruk, demikian kata sejarawan Russia Dudnik yang dikutip artikel tersebut. Waktu di Hindia Belanda melakukan perjalanan panjang dan melelahkan untuk melihat gunung berapi. Pada waktu berkunjung ke Priangan, Nicholas II berusia 23 tahun.

Kedatangan putra mahkota Rusia, Nicholas Alexandrovich, yang tiga tahun sejak kepulangannya dari Garut dinobatkan menjadi kaisar Rusia dengan gelar Tsar Nicholas II, diiringi rombongan pejabat Hindia-Belanda di Batavia. Laporan Bataviasche Handelsblad menyebutkan pemerintah Hindia-Belanda mengerahkan 21 koki untuk melayani calon penguasa Rusia itu. Kunjungan Pangeran Nicholas mendapat liputan dari media Batavia, dan menggerakkan keinginan penduduk kulit putih untuk mengunjungi Garut. Akibatnya, tahun-tahun sebelum pergantian abad, Garut menjadi tempat favorit bagi pelancong kulit putih dari berbagai kota besar di Pulau Jawa.

Bangsawan lain yang menjadi tamu di Hindia Belanda ialah putra mahkota dari Kerajaan Austria-Hongaria (Oostenrijk) pada April 1893. Tujuannya jelas berpelesir. Tidak terlalu jelas siapa nama putra mahkota kerajaan Austria-Hongaria tersebut. Tetapi sebuah artikel dari Majalah Der Spiegel yang ditulis Matthias Schultz berjudul "Diary Rediscovered: Frans Ferdinand 's Journey Around The World", juga dipublikan secara online pada 1 Maret 2013 memberikan konfirmasi namanya Frans Ferdinand Yoseph, putra mahkota Austria-Hongaria berkeliling dunia pada tahun 1892. Usianya baru 28 tahun waktu itu.
Dalam artikel disebutkan bahwa Frans didampingi oleh lebih dari 400 orang, mulai dari pendeta angkatan laut hingga bendahara kerajaan. Selama perjalanan, "FF," yang merupakan inisial resminya, menulis lebih dari 2.000 halaman catatan. Hindia Belanda disebutkan dalam ulasan, perjalanan itu tujuan utamanya India dan Amerika Serikat. Bisa dipastikan hanya Frans yang mengadakan perjalanan fantastis dan besar kemungkinan dialah yang singgah di Priangan.

Dari Batavia rombongan putra mahkota Kerajaan Austria ini bertolak ke Bandung. Rombongan dijamu di rumah Residen siang harinya. Kemudian mereka berangkat pukul tiga sore ke Garut. Mereka tiba di stasiun Garut jam lima sore, pada 13 April 1893. Stasiun dihiasi daun waringin dan cemara. Permadani terbentang di pelataran stasiun hingga keluar halaman. Turut dalam rombongan para pejabat seperti Residen Priangan. Beribu-ribu warga Belanda, Cina, hingga kaum pribumi berdesakan berusaha untuk dapat menyaksikan upacara kedatangan tamu agung ini.

Menak kepala-kepala Soenda,
semoea pake pakean kabesaran
berdjedjer di halaman stasion.
Pangeran Oosterijk dihormati
dengan moesik [...] Ada poen
pakeannja Radja Peotra itu tjelana
dan badjoe Trico Gading tepi blue
aboe hampir semoea rata dengan
penggiringnja (Bintang Barat, 19
April 1893).

Selain Bintang Barat surat kabar Provinciale Drentsche (edisi 15 Mei 1893) menceritakan kisah yang sama mengenai kunjungan sang Pangeran. Tiba di Pelabuhan Tanjung Priuk pada tanggal 11 April, kemudian berangkat menuju ke Weltevreden, di sana sang pangeran telah ditunggu untuk menerima sambutan dari Gubernur Jendral, Residen dan orangorang yang akan membantu dan melayani sang Pangeran selama berada di Hindia- 
Belanda. Di Batavia sang Putra Mahkota menginap di Hotel Des Indes. Esok harinya, Selasa, 12 April ia mengunjungi Buitenzorg untuk melihat Istana Gubernur Jendral dan Taman Botani. Selanjutnya pada hari Rabu ia direncanakan pergi ke Garut, namun tertahan di Bandung, baru pada hari Kamis Franz Ferdinand tiba di Garut untuk kemudian melakukan pendakian ke Papandayan. Jumat sore ia pergi ke Cianjur untuk berburu rusa. Artikel tersebut mengatakan bahwa Pangeran Franz Ferdinand menikmati kunjungannya di Priangan, ungkapan tersebut jelas untuk membentuk citra bahwa Priangan adalah tempat terbaik di Hindia-Belanda untuk dikunjungi.

Garut sebagai destinasi unggulan berlajut sampai dekade pertama abad ke20, dan menjadi lahan bisnis baru, sehingga antara 1900-1917 investasi sektor pariwisata membanjir ke Garut. Hotelhotel berdiri di sekujur Garut, di antaranya Hotel Papandajan, Villa Dolce, Hotel Belvedere, Hotel Van Hengel, Hotel Ngemplang, Hotel Melajoe, Hotel Bagendit, Hotel Kamojang, dan Hotel Cilauteureun. Kemudian VTV mulai menawarkan paket menjelajah Garut dan juga menjadikan Garut sebagai bagian dari paket perjalanan untuk melancong mengelilingi Jawa dan penduduk menangguk rezeki pariwisata dari pertunjukan budaya, penjualan cinderamata, tour guide, penyewaan berbagai keperluan pariwisata, serta penjualan makanan.

Industri pariwisata di Garut pun mencapai puncak keemasannya antara tahun 1920 sampai 1930. Sepanjang 1928 , misalnya, Raja Leopold III dan Permaisuri Astrid, penguasa Kerajaan Belgia, mengunjungi Garut. Komedian Charlie Chaplin, aktris dan penyanyi Renate Mueller dan aktor serta penyanyi Hans Albers keduanya dari Jerman menyaksikan keindahan Gunung Papandayan dan pedesaan Garut dari dekat.
Melejitnya Pariwisata di Priangan sampai para pembesar dari negara lain berbondong-bondong mengunjunginya, terdapat juga peran para Preanger-planters yang berbaik hati menerima dan melayani kunjungan-kunjungan akbar tersebut. Di ceritakan dalam sebuah artikel di surat kabar De Preanger-Bode (edisi 30 Oktober 1905) bahwa Tuan Kerkhoven adalah paling dikenal sebagai tuan rumah yang murah hati dan seorang pemburu yang piawai. Banyak pengunjung yang cukup besar ke Jawa tinggal di wisma "Sinagar", termasuk Grand Duke Sergius dan Alexis dari Rusia, Archduke Franz Ferdinand dari Austria-Hongaria, Pangeran Waldemar dari Denmark dan lainnya. Untuk Archduke Franz Ferdinand ia mengatur perburuan untuk pertandingan besar di Selatan Priangan.

\section{Lahirnya Perhimpunan Pariwisata}

Hindia Belanda sendiri adalah sebuah mahkota yang bertakhtakan permata bagi Kerajaan Belanda, sebagai tanda dari keagungan Zaman Keemasan Belanda ${ }^{2}$. Belanda bangga dengan proyek kekaisaran mereka yang "etis" dan "baik hati" Persepsi positif dari imperialisme Belanda, yang ditunjukkan oleh Belanda dan dikuatkan oleh pengamatan internasional, terbukti dalam representasi penjajah

\footnotetext{
${ }^{2}$ Zaman Keemasan Belanda (Gouden Eeuw) adalah periode yang secara kasar mencakup abad ketujuh belas, di mana Belanda mengendalikan kerajaan perdagangan global dan merupakan salah satu kekuatan politik utama di Eropa. Zaman Keemasan Belanda, dan sampai sekarang, adalah bagian penting dari nasionalisme Belanda (Meulendijks, 2017:36).

3 Vincent Kuitenbrouwer, "Songs of an Imperial Underdog: Imperialism and Popular Culture in the Netherlands, 1870-1960," dalam European Empires and the People. Popular Responses to Imperialism in France, Britain, the Netherlands, Belgium, Germany and Italy, 2011, 90-123; Gouda, Dutch Culture Overseas. Colonial Practice in the Netherlands Indies 1900-1942.
} 
Belanda dalam buku panduan. Vereeniging terlibat dalam retorika Kebijakan Etis dan misi sipil. Dengan melakukan hal itu, mereka menciptakan representasi penjajah Belanda sebagai pemelihara modern dari penduduk asli.

Pemerintah kolonial kemudian semakin menyadari besarnya potensi dari sektor pariwisata tersebut dan mulai terlibat dengan membantu mendirikan biro wisata internasional pertama di Hindia Belanda, yaitu Vereeniging Toeristenverkeer. Pada tahun 1907 J.M. Gantvoort, pemilik Hotel des Indes di Batavia, telah membahas kemungkinan mendirikan organisasi untuk mempromosikan perjalanan luar negeri (Hindia Belanda) bersama J.G. Pott, Direktur Pendidikan Pemerintah dan Industri Lokal. Gubernur Jenderal Joannes Van Heutsz, mendukung gagasan itu. Pada tahun 1908, ia menunjuk sebuah komite yang meletakkan dasar sebagai fondasi awal berdirinya sebuah Vereeniging, dan menawarkan subsidi 25.000 gulden. Pada bulan Maret 1908, Vereeniging didirikan dan memulai kegiatannya (Sunjayadi, 2007: 32).

\section{Priangan sebagai Daerah Tujuan Pariwisata}

Kunjungan-kunjungan para pembesar tentunya mengenalkan keindahan alam Priangan ke turis-turis internasional yang haus akan petualangan-petualangan dunia ketiga yang masih misterius, seperti yang dikatakan oleh David Weir, Terra Fantastica. Daya tarik utama Priangan adalah keindahannya. Priangan memiliki lebih banyak tempat menarik untuk dinikmati dan Priangan memiliki pemandangan yang lebih indah daripada tempat lain. Tidak ada daerah lain dari Jawa yang memiliki begitu banyak gunung berapi di daerah yang relatif kecil ini, dan bukti-bukti dari Gunung Berapi tersebut berupa kekuatan alam seperti mata air panas, kawah aktif, solfatara dan lain-lain, terletak di tengah-tengah vegetasi yang paling indah, memberikan pesona Priangan yang sulit untuk dibandingkan. Kalimat tersebut merupakan salah satu paragraf dalam buku panduan pariwisata yang diterbitkan pada tahun 1913 oleh Vereeniging Toeristenverkeer ${ }^{4}$ mengenai pujian akan keindahan alam Priangan.

Selain itu, iklimnya adalah salah satu yang paling sehat, udaranya yang sejuk dan menyegarkan menjadikannya salah satu resor favorit bagi mereka yang lari ke bawah, atau menginginkan mantra dari panas Dataran Rendah. Dengan potensi bentang alam dan konturnya yang mayoritas berupa pegunungan ditambah dengan tanahnya yang subur dan penduduk lokalnya yang dikenal ramah maka alam Pringan mempunyai nilai keindahan tersendiri, yang tentunya mengundang kunjungan dari para turis untuk menyaksikan sendiri keindahan alam Tatar Priangan. Hal tersebut diperkuat oleh pendapat dari Scidmore dalam bukunya Java: The Garden of The East yang menyatakan bahwa Priangan memiliki pemandangan paling indah di seluruh Jawa, yang seharusnya terkenal di dunia, dan dengan pesona itu seolah mustahil jika dianggap terlalu berlebihan mendeskripsikannya (Scidmore, 1898: 155).

Vereeniging Toeristenverkeer (1913: 24) juga mempromosikan bahwa Keresidenan Priangan mendapat julukan "Swiss van Java" atau Swiss-nya Jawa dikarenakan karakteristik bentang alamnya yang bergunung-gunung, sedangkan dalam buku Nusa Jawa: Silang Budaya Bagian 1 (judul asli Le Carrefour Javanais), Denys Lombard (2005:73) menyematkan kata

\footnotetext{
4 Vereeniging Toeristenverker atau disingkat VTV adalah sebuah perhimpunan yang mengatur arus lalu lintas dan kegiatan kepariwisataan di Hindia Belanda didirikan tahun 1908 pada masa Gubernur Jenderal van Heutsz, dan merupakan tonggak dimulainya industri pariwisata secara resmi oleh pemerintah kolonial Hindia Belanda. Perhimpunan ini disubsidi oleh pemerintah Hindia Belanda tetapi bersifat non-profit (Sunjayadi, 2007: 32).
} 
"Mooi Indie"5 pada gugusan Kepulauan Nusantara.

M.A.W. Brouwer seorang Belanda yang sempat tinggal di Bandung mengatakan bahwa "Bumi Pasundan diciptakan ketika Tuhan sedang tersenyum". Pendapat Brouwer ini bukan merupakan hal yang berlebihan pesona alam Bandung dan Bumi Parahyangan (Priangan) memang begitu indah dan mempesona. Deretan pegunungan yang mengelilingi Kota Bandung dengan berbagai keindahan panorama alamnya juga turut menawarkan kesejukan udara, kolam air panas alami, air terjun, dan suasana dataran tinggi yang elok. Hal ini pun masih ditambah dengan perkebunan teh, kopi, dan kina yang membentang di sepanjang deret dataran tinggi Priangan.

Keresidenan Priangan merupakan salah satu wilayah dimana orang-orang Eropa merasa nyaman untuk tinggal di wilayah ini. Suasana sejuk, nyaman, indah, dan damai begitu mempesona orang-orang Eropa yang mengunjungi wilayah ini. Europa in de Troupen merupakan julukan yang diberikan oleh orang-orang Eropa yang mengunjungi wilayah ini karena keindahan alam tropika Priangan yang terselubungi oleh kesejukan udara khas Eropa. Parijs van Java, Geneve van Java, Montpeiller of Java, dan Switzerland van Java merupakan julukan untuk kota-kota di wilayah Keresidenan Priangan untuk disandingkan dengan kesejukan, keindahan, kedamaian dan keasrian kotakota di Eropa.

Sementara itu geliat turisme di Priangan mengalami masa perkembangan yang begitu pesat dari mulai abad ke-19 hingga awal abad ke-20. Priangan semakin terlibat dalam konstelasi politik negara Hindia-Belanda kolonial sehingga tidak sulit bagi Priangan terutama kota-kota besarnya, khususnya Bandung untuk berkonsentrasi menjadi daerah kolonial modern seutuhnya. Maka tak heran di

\footnotetext{
${ }^{5}$ Mooi Indie merupakan bahasa Belanda yang
} berarti Hindia yang indah. tahun 1920-an hingga 1942 perhatian mulai banyak tertuju pada Priangan sebagai pusat kegiatan turisme utama di Hindia-Belanda.

Melalui kisah-kisah penjelajahan dan penemuan objek-objek wisata terutama wisata alam yang dilakukan oleh Valentijn, Junghuhn, Kinloch dan Scidmore seolah telah memberikan sebuah pijakan pada pembentukan sebuah kota pariwisata modern hingga pembangunan sarana transportasi, komunikasi, dan akomodasi yang meliputi Jalan Raya Pos, stasiun Radio Malabar dan hotel-hotel. Sehingga ketika Tourist Association Garoet berdiri pada tahun 1923, kemudian Bandoeng Vooruit berdiri pada 1926 yang merupakan sebuah perkumpulan yang berbasis pada pengembangan pariwisata. Perkumpulan itu tidak terlalu kesulitan untuk mengembangkan Bandung sebagai kota pariwisata modern yang berangkat dari pariwisata alam.

\section{Akomodasi Penginapan sebagai Penunjang Aktivitas Pariwisata di Priangan}

Sebagian besar tempat untuk turis Eropa yang dipilih untuk ditampilkan dalam buku panduan adalah akomodasi dan infrastruktur untuk tempat wisata yang seotentik dengan kondisi Eropa, akan tetapi pada kenyataannya masih sangat terbatas dan masih mengunggulkan pemandangan asli dan alami khas daerah tropis.

Pada tahun 1906 atau 96 tahun setelah pembangunan Jalan Raya Pos, Karesidenan Priangan telah berubah dari sebuah daerah yang sebelumnya dikenal sebagai schoone slaapter (putri tidur) atau paradise in exile (surga dalam pengasingan) menjadi wilayah yang begitu sibuk dengan aktivitas ekonomi, pariwisata, dan menjadi salah satu pusat aktivitas kehidupan masyarakat kolonial. Wilayah ini memang diberikan kesuburan dan keindahan alam yang luar biasa. Berada di dataran tinggi yang sejuk, Priangan bukan saja menjadi surga bagi 
perekonomian kolonial di abad ke-19, namun juga menjadi "rumah" bagian orang-orang Eropa di Jawa. Seperti yang disampaikan oleh van Hoevel "Hanya alamlah kemudian yang memiliki kekayaan dan keindahan tak terhingga di sini akan dapat mewujudkan angan-angan yang kelak bakal dikenang dan dihargai orang!" (Kunto, 2014: 15-16).

Akomodasi yang direkomendasikan tentunya didominasi oleh standar dari orang Eropa. Hotel-hotel di kota-kota dan stasiun di perbukitan bertujuan untuk memenuhi standar kenyamanan dan kemewahan Eropa, sementara di desa-desa kecil, ini tidak selalu mungkin. Untuk melakukan ekspedisi, buku panduan merekomendasikan pasanggrahan, rumah peristirahatan bagi pejabat pemerintah, yang juga disediakan peruntukan bagi turis. Tempat-tempat hiburan yang dipilih, seperti klub, teater dan ruang musik, juga didominasi orang Eropa. Tempat wisata sejarah dan sosial yang terkenal adalah lingkungan "kota Eropa" di kota-kota besar, yang dipuji karena karakter, monumen, lokasi industri, dan bangunan pemerintah yang terencana dengan baik.

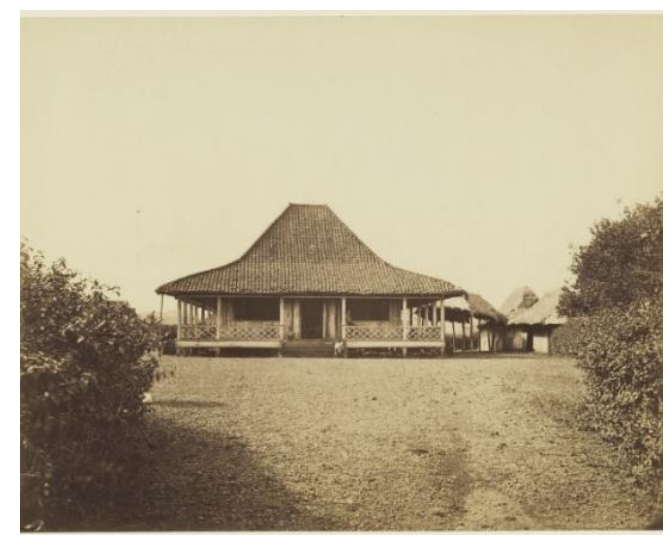

Gambar 1. Sebuah Pasanggrahan di Pangalengan, Bandung Selatan, pada tahun 1880.

Sumber: Woodbury \& Page, 1880.

Beberapa elemen tradisi dari masyarakat asli Hindia Belanda tergabung dalam pariwisata, seperti kebiasaan mandi ${ }^{6}$ dan hidangan rijsttafel ${ }^{7}$.

Masyarakat elit kolonial nyaris tidak ditampilkan dalam buku panduan. Ini dapat dikatakan karena faktanya bahwa mereka tidak menarik bagi para turis borjuis, yang hidupnya tampak mirip dengan para penjajah. Orang Indo-Eropa dari masyarakat ini, yang oleh turis berseragam mungkin dicap sebagai penduduk asli, juga tidak ada dalam buku pedoman, mungkin karena alasan yang sama, karena mereka tidak secara aktif mengolah identitas asli dengan berlaku layaknya masyarakat pribumi.

Dari catatan perjalanan para traveler yang mengunjungi Jawa kita mengetahui bahwa mereka menginap di hotel-hotel yang memang telah ada sejak pertengahan abad ke-19. Selain hotel-hotel tersebut, pemerintah Hindia Belanda bersama pemerintahan lokal setempat mengelola pasanggrahan, semacam penginapan untuk bermalam. Pasanggrahan itu biasanya terletak di pantai dan di daerah pegunungan. Sebuah buku panduan wisata yang terbit tahun 1894 menyebutkan

\footnotetext{
6 Mereka yang berasal dari negeri empat musim, seperti Eropa, tentu tidak terbiasa mandi sore. Namun, mereka harus melakukannya. Kebiasaan mandi di negeri tropis, seperti di Hindia Belanda merupakan suatu keharusan. Saran mandi tersebut dimuat dalam buku panduan Bemmelen dan Hooyer (1896) dan edisi Bahasa Inggrisnya (1897). Praktiknya juga dilakukan di atas kapal yang dijelaskan pada bagian Levenswijze aan boord (cara hidup di atas kapal). Hal menarik adalah penggunaan kata dari bahasa Melayu seperti kammar mandi, dan siram dalam penjelasan mengenai kebiasaan mandi (Sunjayadi, 2018: 18).

7 Hidangan rijsttafel sangat beragam dan berlimpah. Anna Forbes pernah menyebutkan berbagai jenis hidangan rijsttafel, seperti kari, ikan, dan unggas yang dimasak dengan cara digoreng, dikukus. Lalu, ada daging sapi, perkedel jagung, omelet, telur goreng, acar, dan berbagai sayuran. Setelah hidangan rijsttafel, disajikan hidangan ala Eropa, yaitu daging bistik dan kentang goreng (Forbes, 1887: 11).
} 
kurang lebih ada seratus pasanggrahan hanya di Priangan saja (Lombard, 2000: 51).

Sunjayadi (2008:16) menjelaskan bahwa Pasanggrahan itu sendiri merupakan alternatif tempat tinggal sementara untuk para turis selain losmen, herberg dan hotel. Pasanggrahan sendiri sebenarnya merupakan bangunan tempat peristirahatan bagi para raja ratu bangsawan di Jawa. Kemudian bangunan tersebut menjadi tempat tinggal sementara bagi para pegawai atau pejabat pemerintah Hindia Belanda yang sedang melakukan perjalanan ke suatu tempat yang mana tempat tersebut berdekatan dengan pasanggrahan tersebut.

Pasanggrahan juga digunakan oleh para pelancong yang sebelumnya telah mendapatkan izin untuk tinggal di pasanggrahan tersebut. Ada suatu peraturan yang mewajibkan bagi penduduk di Jawa untuk membangun dan merawat pasanggrahan, kewajiban tersebut pada tahun 1882 akhirnya dihapus ${ }^{8}$, dan tidak diketahui alasan dari penghapusan aturan tersebut dan pesanggrahan tetap tumbuh berkembang karena memang biaya operasional yang jauh lebih murah jika dibandingkan hotel, dan lokasinya yang biasanya lebih terpencil dan dekat ke lokasi tujuan wisata. Selain itu juga untuk para turis yang menghindari keramaian biasanya akan lebih memilih pasanggrahan sebagai tempat menginap.

Dalam catatannya, pelancong dari Amerika Eliza Scidmore ketika berkunjung ke Jawa juga pernah bermalam di pasanggrahan yang berada di Tasikmalaya. Kemudian Raja Siam, Chulalongkorn (Rama V) juga pernah menginap di Pasanggrahan Papandayan ketika berkunjung ke sana. Pada malam harinya mereka disuguhi kesenian khas Sunda yaitu wayang golek dan tarian ronggeng (Sunjayadi, 2008:16).

\footnotetext{
${ }^{8}$ Lihat Encyclopedie Nederlandsch Indie 1919
} deel III, 351
Pada umumnya bangunan pasanggrahan sangat sederhana dan bentuk bangunannya masih sangat kental dengan unsur lokal atau bisa disebut dengan gaya bangunan yang lebih cenderung pada rumah tradisional. Dari beberapa sumber foto yang penulis temukan kebanyakan bangunan pasanggrahan masih sangat tradisional dan material utama yang dipakai adalah kayu, hanya beberapa yang bentuknya bisa dikatakan modern pada masanya.

Kehidupan pariwisata di Priangan sangat ditunjang oleh kehadiran para Preangerplanters (Tuan Tanah Priangan) yang banyak mendirikan rumah, bungalow, dan vila di sekitar perkebunan milik mereka. Vila-vila ini kemudian disewakan kepada para pelancong, terutama yang berasal dari Batavia sebagai rumah singgah sementara ketika mereka mengunjungi Priangan (Rush, 2013: 216).

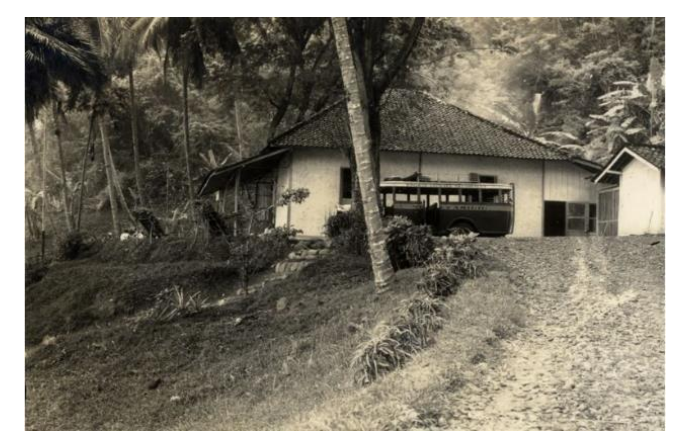

Gambar 2. Sebuah Pasanggrahan di Pelabuhanratu (Wijnkoopsbaai), dengan bus yang membawa turis di sampingnya, 1937.

Sumber: Pasanggrahan met toeristenbus ervoor te Karanghawoe aan de Wijnkoopsbaai West-Java, 1937.

Dalam buku saku (booklet) perjalanan ke Priangan yang dikeluarkan oleh Official Tourist Bureau tercantum hotel-hotel yang menawarkan pelayanan dan keindahan panorama serta suasana perkebunan yang ada di sekitar Karesidenan Priangan menjadi nilai lebih yang dijadikan jualan untuk menarik turis menginap. 
Soekaboemi:

Hotel Selabatoe

Hotel Victoria

Sindanglaya:

Hotel Sindanglaya

\section{Bandoeng:}

Hotel Homann

Preanger Hotel

Lembang:

Hotel Beau Sejour

Hotel Montagne

Garoet:

Hotel Papandajan

Hotel Kurhaus

Hotel Villa Dolce

Tjisoeroepan:

Hotel Villa Pauline

Daftar 1. Hotel di Priangan Tahun 1917

Sumber: Come to Java: Information for

Travellers (Batavia: Official Tourist Bureau, 1917)

Pada booklet tersebut juga dikatakan bahwa hotel-hotel besar di Batavia, Buitenzorg, dan Karesidenan Priangan menyediakan layanan yang modern serta memiliki manajemen yang sangat baik. Hal yang sama berlaku untuk Jawa Tengah, sementara hotel-hotel di tempat-tempat yang lebih kecil, meskipun mereka mungkin memiliki beberapa kekurangan, namun terus ditingkatkan. Beberapa di antaranya seperti Hotel Villa Dolce di Garut, Grand Hotel Selabatoe di Sukabumi, serta Hotel Beau Sejour dan Hotel Villa Isola di Lembang, selain itu juga diitawarkan tempat peristirahatan yang juga menawarkan berbagai sarana rekreasi seperti "Sanatorium Garoet, Ngemplang" di Garut (VTV, 1939: 43). Sanatorium Ngamplang kemudian berubah menjadi Grand Hotel Ngamplang, yang dari kawasan di kaki Gunung Cikurai inilah, sebutan "Swiss van Java" untuk Garut terlahir. Dari tempat bernama Ngamplang tersebut, Kota Garut terlihat begitu jelas dikelilingi pegunungan, layaknya kota-kota di Swiss yang juga dikelilingi pegunungan. Ngamplang terletak empat kilometer dari Kota Garut ke arah Tasikmalaya, tepatnya di Cilawu. Tempat ini berada pada ketinggian beberapa ratus meter di atas permukaan tanah Kota Garut, membuat udaranya jauh lebih sejuk dan segar maka ketika awal dibangun diperuntukkan untuk menjadi sanatorium atau tempat penyembuhan penderita tuberkulosis.

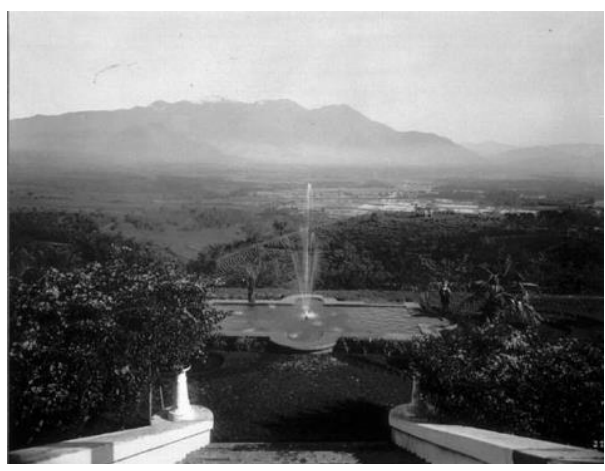

Gambar 3. Pemandangan dari halaman depan Grand Hotel Ngamplang, nampak Gunung Guntur di kejauhan, 1920. Sumber: Weissenborn, 1922.

Bahkan pada awal abad ke-20, para tamu hotel di Jawa seperti dijelaskan dalam buku panduan yang diterbitkan oleh VTV (1913), akan dikenakan biaya dari hari ke hari, apakah mereka menginap sepanjang hari atau tidak, tetapi biaya ini sangat moderat, memperhitungkan bahwa mereka termasuk pelanggan yang menghendaki layanan penuh, sekadar beristirahat, atau hanya membutuhkan kamar mandi bahkan mungkin hanya sekadar berkunjung. Full board di Jawa berarti kopi atau teh sebagai menu minuman pembuka kemudian sarapan, dilanjutkan untuk makan siang, jamuan teh pada sore hari dan diakhiri dengan makan malam.

Kamar-kamar di semua hotel besar memiliki pelayanan yang amat baik dan masing-masing memiliki beranda terpisah dengan kursi-kursi yang nyaman, di mana orang dapat duduk dengan nyaman. Kamar-kamar juga dilengkapi dengan tempat tidur besar, dikelilingi oleh 
kelambu bersih dan semua aksesori kecil yang membuat orang merasa seperti di rumah. Bak mandi, lampu listrik, dan telepon dipasang di seluruh hotel yang besar. Sebuah upaya yang dilakukan oleh para pengusaha bidang akomodasi untuk semakin memikat para turis berkunjung ke Hindia Belanda dengan menghadirkan pelayanan terbaik dan modern.

Tarif hotel di Jawa untuk semua ini hanya $f 6$ per hari di tempat atau hotel yang lebih besar dan $f 5$ per hari untuk tempat atau hotel yang lebih kecil. Hanya ada beberapa hotel di seluruh pulau yang memiliki biaya minimum yang lebih tinggi dan itu tentu saja mungkin untuk mendapatkan kamar yang lebih mahal di hotel besar, serta bungalow pribadi dengan bathtub dan toilet. Harga kemudian bisa naik hingga $f 12,50$ per hari, tetapi secara praktis turis akan menemukan banyak tempat yang masih menyediakan biaya akomodasi yang sangat baik untuk $f 7$ per hari. Semua Hotel memiliki kuli angkut, yang akan memenuhi stasiun kereta dan pelabuhan dan sangat disarankan untuk menyerahkan muatan barang bawaannya ke tangan mereka untuk diangkut ke Hotel. Mobil-mobil, kereta-kereta Hotel (delman atau kereta kuda), atau bus kecil menjemput para turis dari stasiun ke Hotel.

Para Preangerplanters juga berperan besar dalam pengembangan pariwisata dan perhotelan, khususnya di Kota Bandung. Bandung merupakan ibukota dari Karesidenan Priangan. Bandung pada awalnya merupakan sebuah desa kecil dan mulai berkembang semenjak Deandles memindahkan ibukota Kabupaten Bandung dari Dayeuh Kolot ke wilayah ini pada tahun 1810, serta ditetapkannya Bandung sebagai Ibukota Karesidenan Priangan pada tahun 1864 (Kunto, 2015: 17). Bila orang-orang Eropa yang tinggal di luar Priangan lebih menyukai suasana alam dan perkebunan di wilayah ini, maka para Preangerplanters ini pada akhir pekan akan mengunjungi Bandung untuk mencari suasana kehidupan suburban. Di Bandung terdapat beberapa hotel yang telah berdiri semenjak pertengahan abad ke-19 serta menjadi primadona bagi para Preangerplanters dan para pelancong yang berkunjung ke Bandung. Salah satu hotel yang sangat terkenal pada periode pertengahan abad ke-19 hingga awal abad ke-20 di wilayah ini adalah Hotel Savoy Homann (Kunto, 1989: 16).

Hotel Savoy Homann awalnya adalah sebuah rumah penginapan milik keluarga Homann, seorang imigran dari Jerman yang mencoba mengadu peruntungan di Tanah Hindia. Bangunan hotel yang pada awalnya hanya sebuah bangunan bambu ini kemudian direnovasi pada tahun 1880 menjadi sebuah bangunan berarsitektur art deco. Semenjak masa itulah Savoy Homann menjadi hotel terkemuka yang terdapat di wilayah Karesidenan Priangan (Kunto, 1989: 15).

Seiring dengan dibukanya rel kereta api yang menghubungkan Batavia dan Bandung pada tahun 1884, maka Hotel Savoy Homann semakin ramai oleh para turis dan pengunjung yang datang ke Bandung. Selain sebagai tempat menginap dari para pelancong yang mengunjungi Bandung, Hotel Savoy Homann dan Kota Bandung juga kerap kali digunakan untuk mengadakan berbagai kegiatan seperti Kongres Pengusaha Gula (Suikerplanters) Hindia Belanda pada tahun 1887, Kongres Teh Sedunia pada tahun 1924, dan Kongres Ilmu Pengetahuan Asia-Pasifik ke-4 pada tahun 1929 (Kunto, 1989: 16).

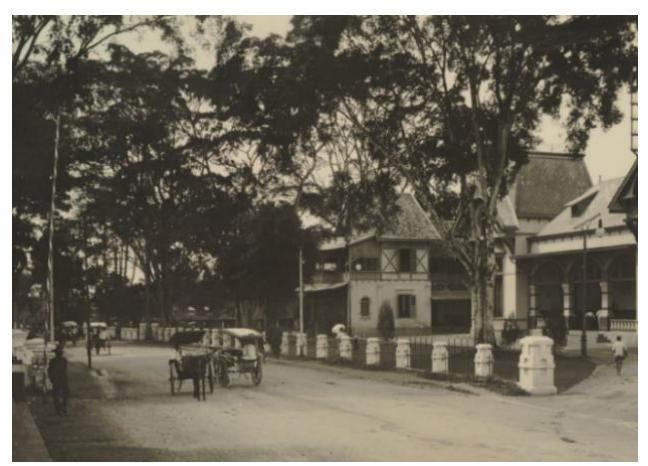

Gambar 4. Hotel Savoy Homann dengan jalan Raya Pos di depannya. Sumber: Verschoor, 1910. 
Bandung masih memiliki
penginapan yang tersohor yaitu Grand
Hotel Preanger, sebuah hotel yang berlokasi cukup strategis karena dilalui oleh Grote Postweg dan pada awalnya didirikan dengan me-redevelopment sebuah herberg atau 'pesanggrahan' serta bangunan Hotel Thiem dan toko di sebelahnya yang dikelola oleh C. P. E. Loheyde (Katam dan Abadi, 2010: 52). Orang-orang Belanda yang mayoritas adalah pemilik perkebunan di Priangan sering datang ke toko milik Loheyde tersebut untuk membeli barang-barang kebutuhan sehari-hari mereka.

Toko yang dikelola oleh Loheyde tidak bertahan lama dan akhirnya mengalami kebangkrutan pada tahun 1897. Kepemilikan toko sekaligus Hotel Thiem lalu berpindah tangan kepada W. H. C. van Deeterkom. Melihat banyaknya para pelancong dari sekitar Priangan yang datang ke kawasan Grote Postweg, Deeterkom akhirnya berniat menggabungkan toko dan hotel kecil yang telah ia beli dengan herberg di sampingnya menjadi sebuah hotel yang berukuran lebih besar dengan gaya arsitektur Indische Empire dan sentuhan gaya Greek Revival.

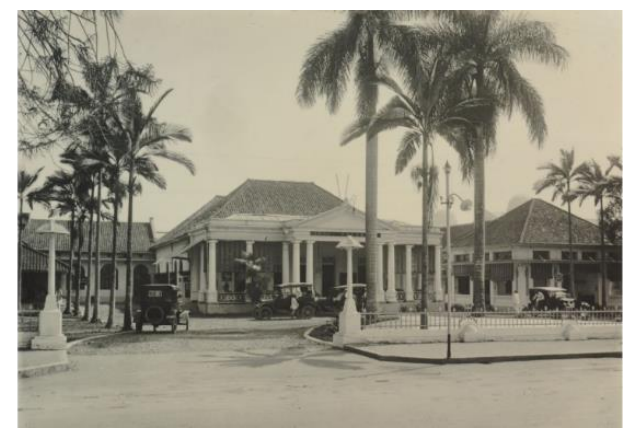

Gambar 5. Grand Hotel Preanger pada Tahun 1925

Sumber: Verschoor, 1925.

Pada tahun 1920 Deeterkom kemudian mengubah nama hotel tersebut menjadi Grand Hotel Preanger, mengambil serapan dari kata priangan yang berarti 'terletak di daerah pegunungan' dan merupakan kata yang populer untuk menyebutkan Jawa bagian barat pada masa itu. (Katam dan Abadi, 2010: 52).

Semakin meningkatnya jumlah kunjungan wisata ke Hindia-Belanda berdampak pula pada tingkat kunjungan turis ke Priangan, Grand Hotel Preanger pun mulai berbenah untuk mengikuti perubahan zaman, maka pada tahun 1929 hotel bergaya Indische Empire ini dibangun ulang oleh C. P. Wolff Schoemaker dibantu oleh muridnya sebagai juru gambar, Ir. Soekarno9. Rancang ulang dilakukan terutama pada bentuk dan gaya arsitektur bangunan; gaya bangunan baru yang diterapkan adalah gaya Art Deco geometrik yang lebih berkesan modern. Rancangan Schoemaker terhadap wajah baru bangunan Grand Hotel Preanger ini dipengaruhi gaya arsitektur Frank Lloyd Wright. Konsep Art Deco pada bagian fasad bangunan inilah yang masih dipertahankan hingga sekarang.

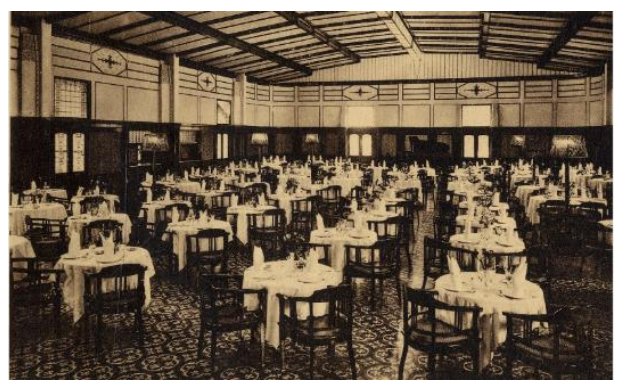

Gambar 6. Ruang Makan Grand Hotel Preanger, 1925

Sumber: Eetzaal in Grand Hotel Preanger te Bandoeng, 1925.

Kemudian di daerah Sukabumi juga pada periode tersebut sudah terdapat penginapan yang representatif. Kota Sukabumi sendiri dalam buku panduan pariwisata tersebut dikatakan sebagai tempat terbaik untuk dikunjungi dan jarak yang tidak terlalu jauh dari Buitenzorg. Sukabumi juga disebutkan memiliki salah

\footnotetext{
${ }^{9}$ Didiet B. Ernanto, "Sejarah Panjang Grand Hotel Preanger Bandung" Harian Sinar Harapan, 16 Agustus 2003.
} 
satu resor kesehatan dan gunung paling menawan yang ditemukan di seluruh Jawa; sebagai tempat yang mempesona pengunjungnya, yang mana hari-hari dapat berlalu dalam kegembiraan tanpa batas dan di mana panas yang memuakkan - yang dialami di kota-kota pantai, dilupakan. Ini adalah resor atau kelas rekreasi favorit untuk para penyandang cacat dan orang yang sedang dalam proses pemulihan, yang menemukan sarana penyembuhan dalam udara segar yang jernih dari perbukitan, malam yang dingin dan hari-hari beriklim sedang di kota kecil ini. Penggambaran tersebut memang bertujuan untuk menarik minat para turis berkunjung ke Sukabumi, walaupun mungkin terkesan berlebihan, akan tetapi Sukabumi memang memiliki daya tarik yang luar biasa sekadar untuk melepas kepenatan rutinitas.

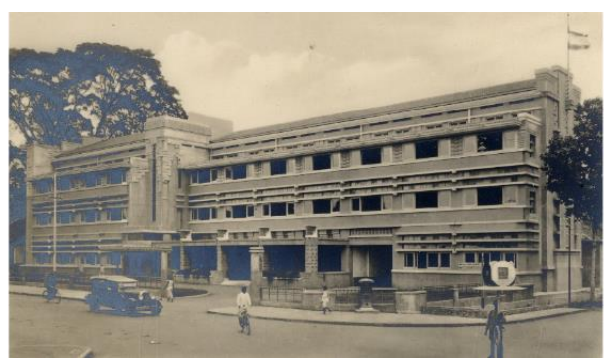

Gambar 7. Grand Hotel Preanger setelah mengalami renovasi, 1930.

Sumber: Grand Hotel Preanger, Bandoeng, 1930.

Dikatakan pula bahwa banyak vila pribadi yang bisa ditemukan di Sukabumi dikelilingi oleh taman-taman dengan vegetasi mewah, dengan pohon-pohon dan bangunan yang megah; terlihat kesegaran dalam embun di pagi hari, mereka saling menarik dan memberi kesan seolah-olah alam dan daerah tropis tidak bisa berbuat apa-apa lagi, karena keindahan yang bersifat definitf. Adapun akomodasi penginapan selain vila dan pasanggrahan terdapat dua hotel besar di Sukabumi yaitu Grand Hotel Selabatoe yang awalnya merupakan sebuah sanatorium, kemudian ada pula Grand Hotel Victoria.
Kebanyakan hotel-hotel besar di Priangan telah memiliki fasilitas-fasilitas yang sangat mewah pada masa itu. Hotelhotel yang ada di Priangan pun ikut tergabung dalam asosiasi hotel HindiaBelanda, yaitu A.B.H.N.I (Algemeenen Bond van Hotel Houders in Nederlandsch Indie). Asosiasi perhotelan tersebut mengeluarkan majalah bulanan yang bernama Hotelblad. Majalah tersebut tentunya menjadi media promosi baik untuk kepentingan pariwisata maupun kepentingan hotel itu sendiri, karena tentunya semakin banyak turis yang berkunjung angka hunian hotel pun pasti akan tinggi.

Cianjur sendiri dalam buku panduan yang diterbitkan oleh VTV (1913: 34), dikatakan sebagai sebuah kota kecil, dan tidak memiliki sesuatu yang menarik bagi turis, akan tetapi seperti semua kota di Jawa, Cianjur ditata apik dengan pohon rindang di sepanjang jalan, dan kebunkebun halus di sekitar rumah.

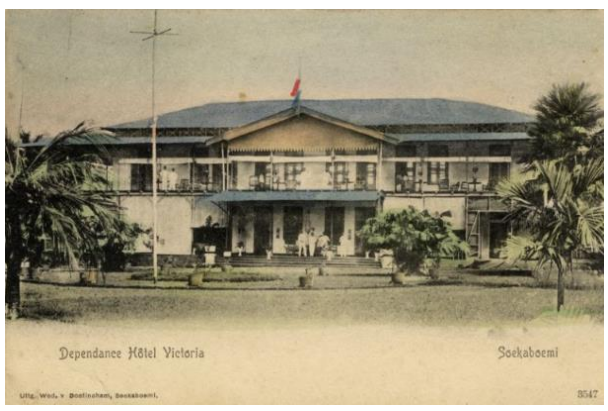

Gambar 8. Hotel Victoria di Sukabumi Tahun 1906

Sumber: Dependance Hôtel Victoria Soekaboemi, 1906.

$\begin{array}{lrrr}\text { Akan tetapi jika kita } & \text { berbicara } \\ \text { Cianjur sebagai } & \text { sebuah } & \text { daerah }\end{array}$ administratif modern, maka Cipanas menjadi bagian di dalamnya dan Cipanas justru jauh lebih dikenal di kalangan penikmat wisata alam dibandingkan dengan nama Cianjur itu sendiri. Terdapat Telaga Warna, Cipanas dan Cibodas yang kesemuanya merupakan tempat yang menarik untuk dikunjungi untuk kemudian 
dinikmati keindahan alamnya. Para turis yang singgah di Cianjur bisa memanfaatkan akomodasi penginapan yang disediakan oleh Hotel Sindanglaya yang sebelumnya memiliki riwayat yang sama seperti Grand Hotel Ngamplang sebagai sebuah sanatorium.

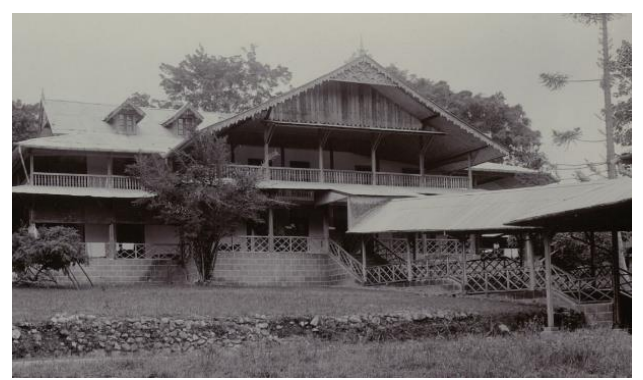

Gambar 9. Hotel Sindanglaya, 1920

Sumber: Grand Hotel Sindanglaja ten noordwesten van Tjiandjoer, 1920.

Seperti telah dibahas sebelumnya bahwa pasanggrahan adalah sebuah penyedia akomodasi penginapan yang jauh lebih murah jika dibandingkan dengan hotel. Tarif untuk menginap di pasanggrahan berdasarkan buku panduan mengenai akomodasi penginapan yang diterbitkan VTV itu sekitar $f 3$ hingga $f$ 13,5 tarif tersebut sudah termasuk sarapan makan siang dan makan malam. Sementara untuk hotel di Priangan berdasarkan dari data List of Principal Hotels in the Nederlandsch Indie yang diterbitkan oleh Travellers Official Information Bureau, diketahui bahwa kisaran tarif untuk menginap satu malam yaitu antara $f 6$ hingga $f 27,5$, dan yang termahal adalah Hotel Isola.

Sebetulnya walaupun terkesan sederhana dan murah, ada banyak hal yang ditawarkan dari menginap atau sekadar beristirahat di pasanggrahan, terutama dalam hal leisure dan pleasure di antaranya pemandangan yang indah seperti air terjun dan hamparan perbukitan yang menghijau, udara yang sejuk karena jauh dari hiruk pikuk perkotaan. Beberapa pasanggrahan juga dilengkapi dengan bak renang (zwembak), lapangan tenis, taman bermain anak-anak sambungan telepon. Jika hotel ada A.B.H.N.I, berbeda dengan pasanggrahan yang pengelolaannya berada di bawah pengawasan Kabupaten, Karesidenan, B.O.W (Burgerlijke Openbare Werken) atau dinas pekerjaan umum, dinas kehutanan, dinas irigasi, pengawas kehutanan dan beberapa ada yang dikelola oleh pribadi. Jika pasanggrahan mengedepankan akomodasi penginapan yang berkaitan dengan kegiatan di lingkungan yang sederhana namun "menyatu dengan alam" sedangkan hotel-hotel tersebut lebih menekankan pada pelayanan yang prima serta kamarkamar yang bersih, rapi, dan modern.

\section{PENUTUP}

Aktivitas pariwisata dengan kebutuhan akan akomodasi adalah satu kesatuan yang mustahil untuk dipisahkan. Layanan penginapan merupakan aspek akomodasi yang utama. Perkembangan akomodasi penginapan yang bermula dari rumah dinas sederhana atau yang di Tatar Priangan biasa disebut dengan Pasanggrahan yang berarti tempat untuk beristirahat, berkembang pesat seiring dengan semakin tersohornya keindahan alam Priangan di kalangan para pelancong sehingga muncul kemudian hotel-hotel besar, baik itu di kota, seperti di Bandung yang terdapat Grand Hotel Preanger, Grand Hotel SavoyHomann, Hotel Isola serta Hotel Beau Sejour dan Hotel Montagne yang berada di Lembang yang merupakan kota satelit dari Bandung. Kemudian Sukabumi dan Cianjur terdapat Grand Hotel Selabatoe, Grand Hotel Victoria, serta Hotel Sindanglaya, dan terakhir di Garut yang pada masa tersebut masih menjadi daerah pedalaman, terdapat Grand Hotel Papandajan, Hotel Villa Dolce, Hotel Villa Pauline dan Grand Hotel Ngamplang. Hadirnya akomodasi penginapan yang menunjang kebutuhan turis, utamanya turis-turis Eropa berdampak positif terhadap geliat turisme di Priangan.

Namun demikian, tulisan mengenai perkembangan akomodasi pariwisata di 
Priangan pada masa kolonial, khususnya dalam aspek ketersedian akomodasi penginapan mulai dari pesanggrahan hingga hotel besar perlu ditunjang dengan data-data tambahan berdasarkan sumber lain yang belum penulis temukan, antara lain terkait bagaimana pola promosi dan fasilitas pendukung aktivitas pariwisata berupa akomodasi penginapan sebelum lahirnya VTV yang menjadi acuan periodisasi pada penelitian ini. Oleh karena itu dibutuhkan penelitian lanjutan yang kritis dan mendalam untuk mengungkapkannya.

\section{DAFTAR SUMBER}

Bintang Barat. (10 Maret 1891).

Bintang Barat. (19 April 1893)

Breman, J. (2014). Keuntungan Kolonial dan Kerja Paksa: Sistem Priangan dari Tanam Paksa Kopi di Jawa, 1720-1870. Jakarta: Yayasan Pustaka Obor Indonesia

Cooper, C. P. (1998). Tourism: Principles and Practice ( $\left.2^{\text {nd }} e d\right)$. London: Prentice Hall.

De Preanger-Bode. (30 Oktober 1905).

Dependance Hôtel Victoria Soekaboemi [Photograph]. (1906). Leiden University Libraries. http://hdl.handle.net/1887.1/item:855472

Eetzaal in Grand Hotel Preanger te Bandoeng [Photograph]. (1925). Leiden University Libraries. http://hdl.handle.net/1887.1/item:839577

Ekadjati, E. S. (1980). Masyarakat Sunda dan Kebudayaanya. Jakarta: PT Girimukt Pusaka.

Ernanto, D. B. (2003, Agustus, 16). Sejarah Panjang Grand Hotel Preanger Bandung. Harian Sinar Harapan.

Forbes, A. (1887). Insulinde: Experience of a Naturalist's Wife in the Eastern Archipelago. London-Edinburg: Wm Blackwood and Sons.

Fulbrook, M. (2002). Historical Theory. London \& New York: Routledge.
Graburm, N. and Jafari J. (1991). Tourism Social Science. Annals of Tourism Research 10 (1).

Grand Hotel Preanger, Bandoeng [Photograph]. (1930). Leiden University Libraries. http://hdl.handle.net/1887.1/item:913866

Grand Hotel Sindanglaja ten noordwesten van Tjiandjoer [Photograph]. (1920). Leiden University Libraries. http://hdl.handle.net/1887.1/item:827337

Herlina, N. (2008). Metode Sejarah. Bandung: Satya Historika.

Kalamakaran, A. (2016, May 18). When Nicholas II caught Singapore off guard. Retrieved from http://rbth.com/arts/history/2016/05 /17/when-nicholas-ii-caught-singaporeoff-guard_593667.

Katam, S., \& Abadi, L. (2010). Album Bandoeng Tempo Doeloe. Bandung: Khazanah Bahari.

Kinloch, C.W. (1853). Rambles in Java and the Straits in 1852. London: Simpkins, Marshall and Co.

Kunto, H. (1989). Savoy Homann: Persinggahan Orang Penting, Bandung: Bidakara Hotel Savoy Homann.

Kuntowijoyo. (2013). Pengantar Ilmu Sejarah. Yogyakarta: Tiara Wacana.

Lombard, D. (2005). Nusa Jawa: Silang Budaya, 1 bag. Batas-batas Pembaratan. Terjemahan. Jakarta: Gramedia Pustaka Utama.

Meulendijks, H. (2017). Tourism and Imperialism in the Dutch East Indies: Guidebooks of the Vereeniging Toeristenverkeer in the Late Colonial Era (1908-1939). Tesis Tidak Diterbitkan. Utrecht: Utrecht University.

Pasanggrahan met toeristenbus ervoor te Karanghawoe aan de Wijnkoopsbaai, West-Java [Photograph] (1937). Leiden University Libraries. http://hdl.handle.net/1887.1/item:700700

Provinciale Drentsche en Asser Courant. (15 Mei 1893). 
Rush, J. R. (2013). Jawa Tempo Dulu: 650 Tahun Bertemu Dunia Barat 1330-1980. Depok: Komunitas Bambu.

Scidmore, E. R. (1898). Java: The Garden of the East. New York: The Century Co.

Schulz, M. (2013, March 1). Franz Ferdinand's Journey around The Word. Retrieved from http://www.spiegel.de/ international/zeitgeist/diary-of-archdukefranz-ferdinand-details-1892-journeyaround-world-a-886196.html

Sjamsuddin, H. (2012). Metodologi Sejarah. Yogyakarta: Ombak.

Spillane, J.J. (1987). Ekonomi Pariwisata: Sejarah dan Prospeknya. Yogyakarta: Kanisius.

Sunjayadi, A. (2007). Vereeniging Toeristenverkeer Batavia (1908-1942). Jakarta: Penerbit FIB UI.

Sunjayadi, A. (2008). Mengabadikan Estetika: Fotografi dalam Promosi Pariwisata Kolonial di Hindia Belanda. Wacana, Vol. 10 No. 2, Oktober 2008, 301-316.

Sunjayadi. (2018). Akulturasi dalam Turisme di Hindia Belanda. Paradigma, Vol. 8 No. 1, Juli 2018, 11-23.

Termorshuizen, G. (1993). In de Binnenlanden van Java. Leiden: KITLV.

Vellas, F., \& Becherel, L. (1995). International Tourism: An Economic Perspective. Basingstoke: Macmillan Press Ltd.

Vereeniging Toeristenverkeer. (1913) Illustrated Tourist Guide to Buitenzorg, The Preanger and Central Java. Batavia: Official Tourist Bureau.

Verschoor, K. H. (1910). Hotel Homann aan de Groote Postweg te Bandoeng [Photograph]. Leiden University Libraries. http://hdl.handle.net/1887.1/item:824836

Verschoor, K. H. (1910). Hotel Preanger te Bandoeng [Photograph]. Leiden University Libraries. http://hdl.handle.net/1887.1/item:824922

Weir, D. (2011). American Orient: Imagining the East from Colonial Era through The Twentieth Century. Boston: University of Massachussets Press.
Woodbury. (1880). Pasanggrahan te Pengalengan ten zuiden van Bandoeng [Photograph]. Leiden University Libraries. http://hdl.handle.net/1887.1/item:790782

Weissenborn, M. M. (1920). Ngamplang bij Garoet op Java was eerst een sanatorium, later, tot 1946, een luxe hotel [Photograph]. Collectie Stichting Nationaal Museum van Wereldculturen. https://hdl.handle.net/20.500.11840/8117 